\title{
APPLICABILITY OF DIFFUSION OF INNOVATION THEORY IN ORGANIC AGRICULTURE ${ }^{1}$
}

\author{
Mirela Tomaš Simin², Dejan Jankovič³
}

\begin{abstract}
Summary
The authors discuss the possibility of applying the theory of diffusion of innovations in the concept of organic farming. Agricultural and food sector has been exposed to significant changes over the past two centuries. That was very significant for the theory of diffusion of innovations that sought to better understand the process of knowledge transfer and adoption of innovations. Organic farming has developed as a response to the environmental and other problems of conventional agriculture. Also, it is a reaction to some issues regarding rural development. By introducing the theory of diffusion of innovation, the aim of the paper is to take into the consideration the possibility of its application to the organic system analysis. By that, we wish to take into account all the specifics which enable to observe the system of organic farming as an innovation itself. The authors conclude that the theory of diffusion of innovations can be used in the research of organic farming systems, with the respect of all characteristics and particularities of organic farming.
\end{abstract}

Key words: organic agriculutre, innovation, diffusion of innovation, adoption of innovation.

JEL: Q01, Q56, Z13

\section{Introduction}

Agriculture has always been a specific economic activity. Therefore, it has specific characteristics associated with knowledge, innovation and transfer of new technologies within the knowledge and information system. The major changes that have affected the food sector in the period after the Second World War must be considered with the help of global

1 Paper is a part of research projects financed by the Ministry of Education, Science and Technological Development of the Republic of Serbia III 46006 "Sustainable agriculture and rural development in terms of the Republic of Serbia strategic goals' implementation within Danube region“ and project ON 179028 ,Rural labor market and rural economy of Serbia - diversification of income and poverty reduction“.

2 Mirela Tomaš Simin, M.Sc., teaching assistant, University of Novi Sad, Faculty of Agriculture, Trg Dositeja Obradović 8, 21000 Novi Sad, Serbia, E-mail: mirelat@polj.uns.ac.rs

3 Dejan Janković, Ph.D., assistant professor, University of Novi Sad, Faculty of Agriculture, Trg Dositeja Obradović 8, 21000 Novi Sad, Serbia, E-mail: jankovic@polj.uns.ac.rs

EP 2014 (61) 2 (517-529) 
approaches, such as those developed in the social theories of the time and date. Exploring the causes and effects of these changes caused the process of knowledge transfer and diffusion and adoption of innovations in this field to be analyze from a sociological point of view. When accessing such analysis one should take into account the diversity of peasant society and the ways in which innovation and knowledge are transfered and adopt.

The aim of the paper is to introduce the theory of diffusion of innovation and the possibility of its application in the assessment of organic farming. Organic farming has developed in response to the growing problems of conventional agriculture, especially in relation to the environment. Although it is farming, organic agriculture, in this context (diffusion of innovation) is significantly different from conventional production. For example, in organic agriculture there is an increased volume of indigenous agricultural knowledge. For these reasons, it is necessary to understand the ways that knowledge is being transfered into organic agriculture and to identify fundamental differences of this process in conventional and organic production.

According to Petrović et al. (2004) rural communities are part of a global society and share its destiny. However, in many ways, they are very specific social organisms, especially when it comes to changes in the countryside and agriculture. Therefore, the process of spreading (diffusion) and introduction (adoption) of innovation, knowledge and technology - which is usually at the center of social change in rural communities - is a complex and contradictory process.

Associated with organic production is the "production of ecological culture" - new lifestyles in modern society and its way of life. According to Ćifrić (2003) ecological (or organic) agriculture has existed as a practice in a traditional peasant society. Here, it must be noted that, even though being similar to traditional agriculture, organic agriculture is indeed modern agricultural practice based on up-to-date scientific knowledgeorintegrationofmodernscientific knowledge with the indigenous knowledge of local farming practices and circumstances. With the emergence of industrial (conventional) agriculture and its consequences for humans and the environment, organic farming became theoretical, environmental, technological, social and political problem and current world topic (Ćifrić, 2003). Organic farming is the result of a much broader context of modern development and environmental discourse than agriculture itself and the specific social circumstances. Incentives are most often from practice (health, economic, environmental, social), (see: Čikić, Petrović, 2010) and theoretical discourses (the search for a new development paradigm). Organic agriculture - along with a number of other alternative food movements - according to some authors (Lockie, Halpin, 2005) produces food «not only good to eat but good to think". Vlahović et al. (2011) defined organic agriculture as the most acceptable form of agriculture in the context of environmental criteria and it is not just "farming without the use of artificial chemicals".

While the analysis of the historical development of organic agriculture is present in the world and national literature (Lampkin, Padel, 19945; Lazić et al., 2008; Offerman, Nieberg, 2000), systems analysis of mutual relations of producers, researchers and extension agents in organic agriculture has so far been neglected (Aeberhard, Rist, 2008). Rogers (2003) stated that the 
adoption of new ideas, even when it shows clear advantages, is a difficult process. According to Rogers (2003), many innovations require a certain period of time before becoming adopted by wider population/users. Problem that arises is how to shorten this period. Also, according to Rogers (2003), diffusion is the process in which an innovation is communicated through certain channels over time among the members of a social system. It is a special type of communication, in that the messages are concerned with new ideas (consult: Leeuwis C. (2008): Communication for rural innovation: Rethinking agricultural extension).

The problem of diffusion and implementation of innovations in agriculture should not be considered simplistic, so one would possibly thought that the process of diffusion and implementation of innovation will take place successfully if there are sufficient financial resources, agricultural experts, awareness of adopters, access to innovation etc. In the last century, the experiences of many countries (particularly less developed and developed ones) have often proved unsuccessful in modernization of agriculture and rural development. Although the activities were (sometimes) carefully prepared, generously financed and supported otherwise by the governments of these countries and influential international organizations, the expected outcome haven't occured (Petrović et al., 2004). Failure of Training \& Visit extension approach is a good example of previous statement.

\section{Methodology and data sources}

The aim of the paper is to introduce theory of diffusion of innovation and identify possibility to apply this theory to the organic production system, taking into account all its specifics. Descriptive method was used to study the problem, combined with the method of abstraction. With the deduction model, existing theoretical knowledge was considered. Method of induction was used in generalization of the data and conclusion. Secondary sources of literature were used as well as primary data resulting from the research in mentioned projects.

\section{Theory of diffusion of innovations}

Diffusion theory, developed in the U.S. by rural sociologists, is a very important theory that describes the process of change, for example, diffusion of innovations in a community. This theory attempts to predict the behavior of individuals and social groups in the process of adoption of innovation, considering their personal characteristics, social relations, time factor and the characteristics of the innovation (Padel, 2001).

Innovation is an idea, practice or object that is perceived as new by an individual or other unit of adoption (Rogers, 2003). Pejanović and Njegovan (2009) stated that "innovation is a new method of production of known goods, discovery and production of new types of products, introduction of new production combinations”.

According to Rogers (2003), diffusion of innovation is a kind of social change. It is a social process that involves interpersonal communication. Communication is a process in which participants create and share information with one another in order to reach mutual understanding. Diffusion is a special form of communication related to new ideas. It is 
a specific form of social change, defined as a process by which alteration occurs in the structure and function of a social system. Hall (2003) states that in the study of innovation the term diffusion is most often used to describe the process by which individuals or groups (companies) in the society/economy adopt a new technology or replace old technology with new.

Innovation as a social construction is created in interaction of awareness and the need for innovation (utility, acceptability, compatibility of innovation, the need to overcome the existing and well-known), openness and focus on creating a system of social innovation, creative personalities. Anyway, innovation is the result of synthesis of innovative individuals - talented and brilliant personalities, their physical and mental characteristics, as well as social conditions and scientific environment, and a position within the wider scientific community (Janković, 2005). In this regard Aeberhard and Rist (2008) states that new ideas can be generated by individuals, but only through collective cooperation in the process of social interaction. The adoption of innovations in agriculture is positively correlated with the level of education of the adoption unit (farmer), the experience and the property of holdings (measured in assets of the farm), (Rijn et al., 2012).

The roots of the modern theory of diffusion of innovations can be found in the research that was most represented in the American rural sociology from the 1940 's to the 1970 ' ${ }^{4}$. Scientific research area of diffusion of innovation, especially in rural areas and agriculture, was one of the main themes of early American rural sociology and it was developed for practical needs (Janković, 2005). Sociological research of the diffusion of innovation developed mostly from antropology, due to its qualitative methodology. However, as Rogers noted (2003), creation of the paradigm had to wait for the the rural sociology tradition which has the highest percentage of participation in studies of diffusion of innovations. According to Rogers (Rogers, 2003; Janković, 2005; Padel, 2001), one of the most important research associated with the diffusion of innovations was the research study of Ryan and Gross (1943) who studied the diffusion of hybrid corn among North American farmers. This research led to the establishment of «research paradigm» in the study of diffusion of innovation, especially in the U.S.A. ${ }^{5}$. In this study (Ryan, Gross, 1943), empirical data show that based on the time of adoption of the specific sample, categorization of adoptive paterns can be made and it will show cumulative curve that takes the (famous) S-shape, while in the inspection of frequency of adoption it has a shape of a bell.

At first glance, the diffusion of innovation theory looks good and is applicable to the process of adoption of organic farming (Padel, 2001). However, there are some concerns. The diffusion theory was developed in the 1980 's, during the paradigm of productivity of

4 It should be noted that a significant legacy for future researchers of diffusion process was given by Gabriel Tard with its study of the diffusion process and the "law of imitation", almost at the same time when some anthropologists and researchers have dealt with evolutionary concepts (Janković, 2005).

5 The paradigm was influenced beyond U.S.A., since most researches on the subject in the world was often performed according to the American model. 
agriculture and "green revolution". Organic farming is a challenge to this paradigm, because it is characterized by a series of goals related to environmental protection and sustainable development (Padel, 2001). Organic farming is the closest to the ecological principle of sustainable agriculture, which is, compared to conventional agriculture, rather innovative (Beauchesne and Bryant, 1999). Considering organic agriculture as complex of agricultural innovations, Sutherland and Darnhofer (2012) stated that it has becoming more acceptable nowadays, especially "when it was seen to be profitable, especially if it was more profitable than neighbouring conventional farms".

According to Padel (2001), diffusion theory could help understanding the process of diffusion of organic agriculture in a community and the way in which this process can be supported and improved, for example, through the information system in agriculture or agricultural extension.

\section{Organic agriculture and diffusion of innovation}

After the Second World War, in accordance with the increasing global need for food, conventional agriculture prevails and takes growing trend. Companies that have been producing synthetic chemicals for military purposes faced the lost of market. Therefore, they had to turn to new customers - farmers. Pharmaceutical companies began to offer the full range of toxic chemicals in the form of pesticides, growth hormones, fertilizers and others. Their application combined with heavy machinery and intensive irrigation, gave very high yields. Thus began the era of the development of agriculture which was later called the "green revolution". Technology and agricultural chemical products were exported to developing countries with the purpose of (or justification) stoping the world hunger. In addition, the poor were offered genetically modified grain seed which gives a high yields while, at the same time, is resistant to pesticides (Puđak, Bokan, 2011). However, in later years, there was a manifestation of the negative impact of conventional agriculture on the environment. On that ground, the idea of organic farming was borne.

By the end of the 1960's, as a result of innovations, the rotation of crops is considered obsolete and many farmers believe that they have almost complete freedom of management of production, at least in terms of weed control. Ward states that (according to Morgan, Murodch, 2000) "thirty years, since 1950 until the 1980s, were witnesses of the chemical revolution in British agriculture. Production practices changed and the use of pesticides in general terms" became the basis of crop production. This revolution had set agriculture on a separate development path associated with the constant use of innovative technology, which aimed to increase output and productivity. Scientific researches in agriculture and food production in the pre-war and post-war period (especially) were mainly concentrated on the search for technological solutions that will increase production efficiency. The key instrument of government policy was the research and development aimed at encouraging primary production (Lowe et al., 2008).

Tovey (1997) stated that, according to the dominant perspective of rural sociology in developed countries, modernization of agriculture is primarily related to the production of 
more output using less rural resources. The dominant trend in the countryside during the past century or more has been the decrease of resources usage - primarily rural labor and, later, agricultural land - for purposes outside the agricultural production.

When studying the diffusion of innovations in agricultural production, one must have in mind that, in comparison with scientists` and researchers' focus on how and why things happen, for farmers is of particular importance that the applied production method really works. "If there is a positive result, farmers are willing to use a certain farming method and to accept the underlying scientific or philosophical explanation" (Aeberhard, Rist, 2008).

Beauchesne and Bryant (1999) defined organic agriculture as a social and technological alternative to conventional production, although in this dichotomy lays something more complex reality. Organic farming is often associated with the "old" method of production and often looks like "return to the past". However, it should be noted that there is a difference between organic agriculture and peasant agricultural production, as Ćifrić (2003) calls it. According to Ćifrić (2003): «it is sufficient to say that the peasants' production is fundamentally ecological (organic) production as farmer's work has always focused on sustainability. Not only the production is ecological, but also rural way of life and rural society in general". Ecological (organic) agriculture is not a conservative concept. It should not be understood as a request to: a) return to the pre-industrial mode of production in terms of technological obsolescence and b) return to the rustic, traditional way of life which includes a return to the old relations in the family, including gender and generation relations, etc.

Ecological (organic) agriculture is a social innovation. In this way, organic agriculture is not only a new form of farming. It is a social innovation aiming to change patterns in the relation between community and environment. It should be understood as: a) the abandonment of domination paradigm of industrial agriculture, b) the possibility of additional employment of labor on the family farm and society, c) benefit of quality products in small areas, d) boost of the development of "closed" system of production, e) the increase use of natural energy and organic processes. Organic farming is contemporary version of peasant agriculture because it assumes: a) recognition of some experiences of the peasant economy (especially those which are related to a balanced relationship with nature) and b) involves the application of science in a way that guarantees its ecological character (Ćifrić, 2003). Ecological (organic) agriculture is the idea (and practice) which represents a change in thinking about food. It goes beyond the question of the nutritional composition of our meals and becomes a part of our lifestyle. Some authors (Lowe et al., 2008) call food produced according to organic principles as alternative food.

Despite of some differences in the definition of the concept of organic farming, the main goal of this system of production is sustainability. The term «sustainable» is used in a broad sense, including economic, social and natural sustainability. Katic et al. (2010) state that «organic farming, as a special form of agricultural production, is the basis for sustainable agricultural production. It is a form of production that best meets the requirements of environmental protection and sustainability principles". The development of organic agriculture is 
primarily related to the farmers, who were the pioneers in this production. Knowledge and information on organic farming was often distributed through informal networks, initially. This was followed by the establishment of the different organizations and associations in organic agriculture, sometimes encouraged by individuals interested in the development of agriculture and rural development. In the early stages, research, as an important factor of agricultural development, played a minor role (Padel, 2001).

Motives for conversion to organic production are different. The pioneers of organic agriculture primarly stated philosophical and ideological reasons (Padel, 2001; Puđak, Bokan, 2011), such as the connection with nature, a holistic approach to life, the desire to move away from the capitalist system of production and life. Nowdays, motives are much more profane and associated with the economic benefits of organic agriculture, expressed through a premium price which, under certain conditions, can enable a profit equal to or higher than in conventional production (Offerman, Nieberg, 2000). By changing motivation, community of organic producers takes on new characteristics. This phenomenon is also associated with a change of political circumstances relating agriculture. At the beginning or in the formation of the organic movement, this production system represented an opposition to the authorities and policies. Aeberhard and Rist (2008) stated that organic agriculture is currently supported by subsidies in many countries. The course of the acceptance of organic farming was carried out through phases: in the first phase, the organic movement has been stimulated by the pioneers (innovators, according to the theory of diffusion of innovations) that were developing new ideas and concepts and not necessarily follow the usual way of life. Pioneers were often seen as the outsiders and newcomers. They were constantly in a position to defend their views and ideas. These created a strong social cohesion among the pioneers in organic farming and promote the intellectual and spiritual connection. Today, organic farming is regulated by law, well positioned in the market, widely accepted in society and organic producers have no more a role of outsiders.

Sociological framework of understanding the process of diffusion of innovations in rural areas and agriculture is analyzed by researchers (see Jankovic, 2005; Čikić, Petrović, 2013) indicating the complexity of this process and sociologically relevant factors that affect it. Compared to organic production, Čikić and Petrović (2010) stated that if the development of organic farming is regarded from the farm perspective, a key factor in making a decision about the conversion from conventional agricutlure is the awareness and knowledge of farmers (and other members of the household who participate in making decisions) about what organic farming means, what are the preconditions for engaging in the production, what organic farming can bring to the farm, etc. As organic production evolve, a significant change in the organization of work on the farm and the role of knowledge and information is essential to the successful execution of a change.

The question is whether the diffusion of knowledge in organic farming differs from those in conventional agriculture, and if so, what is the major distinction? The answer to this question must be sought in the general factors that determine the diffusion of knowledge in agriculture (Čikić, Petrović, 2010). The entire process of diffusion of knowledge, 
innovation and skills in organic farming is impossible to fully consider, much less evaluate its effectiveness, if one do not have in mind the "general characteristics of agricultural production and the level of development of agricultural area, the level of development and characteristics of organic production, the general characteristics of organic farmers and farms, characteristics of the agricultural policy, the institutional framework of the whole process (from the state through research institutions to agricultural extension services) etc" (Čikić, Petrović, 2010). From this list, one should not leave out the influence of the local community, migration effects, the degree of urbanization, the impacts of different social groups (such as Manufacturers Association) and the broader macro-factors such as social structure, type and openness of society for innovative processes (in terms of sociocultural value system) and so on. All these factors provide a in-depth explanation of the individual as a «unit of adoption" which actually represents the "tip of the iceberg" and is always "situated in specific social relations that directly and indirectly determines its social action and thus the adoption of innovations" (Janković, 2005).

According to the theory of diffusion of innovations, the assumption is that innovators are better informed compared to late adopter and have more social capital in, but also outside of their local community. In organic farming, there are a high proportion of producers with urban origin, with high level of academic education and less experience in the agricultural production. Early researches suggest a lack of social acceptance of organic farmers as a result of the conversion process, while in subsequent studies this relationship is less important (Padel, 2001; Puđak, Bokan, 2011). Organic producers with the urban origin can be prepared for such difficulties, because they are less dependent of the local community. On the other hand, they are not taken seriously as an example because they are not considered real farmers. Researches suggest that early adopters are more oriented to the commercial aspects of production, that is to a viable or financial motives compared to sustainable motives. This may be correlated with the increasingly difficult position of agriculture (Padel, 2001). These so-called "generalizations" are more or less argued in many studies of diffusion of innovation and they are reported by Rogers in the analysis of all relevant elements of the diffusion process, ie. innovation decision process (Rogers, 2003).

The process of testing or the phase of experimenting with innovation, as one of the most important in making a decision on their adoption of organic production, is significantly different from the same phase in the conventional agriculture, because of its very technological and organizational specifity (Čikić, Petrović, 2010). Sutherland and Darnhofer (2011) have also confirmed that in their study, where some participants indicated how their decisions was affect by the ability to «experiment» or «try out» organic production before the conversion process. According to the diffusion theory, the innovation should meet certain criteria in order to be (easily) adopted. One of them is obvious economic advantages. Organic agriculture is a complex system which affects the entire household, not just farm as a specific production unit. The application of the diffusion theory on such a complex system is not common, because most of the research of diffusion is related to the adoption of a single new technology. It was observed that farmers often experiment with innovation, experimenting on the part of households, for example growing organic vegetables, which can be linked to «trying» the 
organic agriculture (Padel, 2001). Some researches suggest that for some farmers the decision to switch to organic production system payed off(Offerman, Nieberg, 2000). If one discovers the benefits of the adoption of innovations, and if there is an internal need for the adoption of innovations, the farmer will adopt the innovation (Janković, 2005).

In the organic agriculutre it is not just the technical aspects but anthropological relation of man and Earth and the earth as a specific plot (Ćifrić, 2003). However, when researching different farming systems, one should always bear in mind the shortcomings of it. So Kirchmann and Thorvaldsson (2000) reported that many problems related to conventional agriculture and environment are also present in organic farming. However, this analysis is beyond the scope of this paper, although it remains an open question for future research.

\section{Conclusion}

Puđak and Bokan (2011) emphasize that holistic approach in analysis is too complex. Therefore, most of the scientists simplify their analysis to a specific factor or characteristic. Taking into account all economic, nutritional, environmental, and social factors together is too much trouble, and maybe (quantitative) impossible. In addition, and perhaps more important is the explanation of Kuhn's paradigm. If monocultural farming and the entire system of conventional agriculture, together with the economic goals and global markets, is understood as part of the same (scientific) paradigm, it is not surprising that many arguments, even if scientifically validated "against" these practices, does not mean that they will be rejected. New scientific knowledge about the harmful effects of conventional agriculture and multiple benefits of organic farming simply does not fit into the current system of truth in current paradigm ${ }^{6}$. In this regard, it should be noted that some of the most serious criticism of the consequences of modernization and technological, economic and structural determinism are still present in the social sciences of developed countries (those disciplines that deal with agriculture and rural development), (Janković, 2012). In these, modernization is seen as «a powerful political and economic project in which the state, science and agribusiness have been central" (van der Ploeg, 1995). Social theory that deals with these issues has witnessed increasing quantity of evidents that the modernization paradigm in agriculture in developed countries, in some respects, has long been experiencing crisis. This paradigm is marked by exogenous and sectoral approach, with an emphasis on specialization in agriculture, land policy (the enlargement) the concept of adoption of new technologies, encouraging the mobility of labor and capital from farms that are not considered "optimal" for the dominant development trends (Janković, 2012). The crisis of this development paradigm was sensed

6 They fit in the paradigm as a set of scientific hypothesis/statements which enables us to understand reality. Nevertheless, according to Kuhn, paradigm also entails social values which determine type of the research, method to be applied etc. Because of this, paradigm (as science, in general) is not excluded from the influence of social circumctances (see: Kun, T. 1974. Struktura naučnih revolucija, Beograd: Nolit.). The question whether knowledge about the benefits of organic farming fits to the current system of truth is much more related to the issues that go beyond strict boundaries of sciences. It is a question of power relations in the production/economy sphere.

EP 2014 (61) 2 (517-529) 
at the end of the last century, through the emergence of a large surplus of food and instability of agricultural markets as a result of modernized and globalized agriculture. Since then, socio-economic considerations for the future of European agriculture and its changing role in modern European societies has begun. This role is now being pondered in terms of deviation from productivism in agriculture, which is regarded as virtually synonymous with the postwar modernization model. Post-productivistic transition imposes a different trend (Woods, 2005): extensification, farm diversification, an emphasis on countryside stewardship and enhancing the value of agricultural products.

The conventional agriculture is in the crisis from the 1970 's so that the difficulties of the economic situation of farmers came to the fore. One of the important aspects of these difficulties is their dependence on external, specialized sources of knowledge, because modernization (according to productivism model) makes farmers weak in ability to explore new farming practices. In the organic system, farmers have to forgott practices that are used in the conventional production system, and must re-learn how to practice agriculture in a way that is more in line with the eco-system and the rhythm of nature. This process of food production also involves learning new forms of distribution some of which are highly localized. Organic agricultural production is a possible solution for certain problems of conventional agriculture. However, if farmers want to convert to organic production, they have to adopt new knowledge and innovation. Refusal to re-educate is as a barrier to organic agriculture same as poor financial incentives, because without the public support designed to help farmers to acquire the skills needed for this type of production, the burden of conversion will fall only on a few farmers committed to preserve the environment.

Ecological (organic) agriculture is not simply just agricultural production, but it assumes a definite social system - a society, which in itself has not only developed the rational dimension of the application of new knowledge in agricultural production and processing, but also a set of values (moral and aesthetic) that legitimize such production and moral action (Ćifrić, 2003). Janković (2005) states that it must be concluded that sociological analysis and explanation of the phenomenon of diffusion of innovations in society, especially in peasant society, must take into account the undeniable fact - traditional peasant society is transforming.

Theory of diffusion of innovations can be used in order to obtain a better understanding of the process of diffusion of organic production systems, especially the process of adoption of innovations in this type of the production. Of course, the theory must be applied with caution, bearing in mind the limitations that come with it, especially in relation to organic farming which is a complex set of innovation. Taking into account the mentioned elements of the diffusion of innovation, it is necesary to draw attention to the characteristics of innovation (eg, relative advantage, compatibility, complexity, triability, observability) that are usually absent in such systems ${ }^{7}$. A similar situation applies to the complexity of innovations, which is present in the organic production in the form of the key rules of production, certification,

7 Especially for long term effects that are present conserning environment or well-being and health of the consumer, as well as the public interest because the producers do not need to be aware of these when deciding on the acceptance of the principles of organic production. 
etc., which can not be ignored. It is, therefore, important to support these values and practices through agro-environmental programs as instruments of agri-environmental policy, as it provides producers exchange for the provision of environmental management, offering regular payments which contribute to raising awareness and values, and practices which supports the concept of sustainability. Accordingly, we agree with the Jankovic statement (Janković, 2005) that the theory of diffusion of innovation, no matter to critical remarks, however, reached a level of development where its findings must be considered a significant contribution to the explanation of the process of diffusion as a form of social change. In accordance with the principles of this theory organic production can be supported and spread among producers with significant impact on their incomes, but also protects the public interest in terms of environment, quality and safety in the food chain, consumer health, etc.

\section{References}

1. Aeberhard, A., Rist, S. (2008): Transdisciplinary co-production of knowledge in the development of organic agriculture in Switzerland, Ecological Economics, doi:10.1016/j. ecolecon.2008.08.008

2. Beauchesne, A., Bryant, C. (1999): Agriculture and innovation in the urban fringe: the case of organic farming in Quebec, Canada, Tijdschrift voor Economische en Sociale Geografie, Vol. 90, No. 3, Blackwell Publishers, UK, pp. 320-328.

3. Ćifrić, I. (2003): Značaj iskustva seljačke poljoprivrede za ekološku poljoprivredu, Sociologija i prostor, Institut za društvena istraživanja Zagreb, Zagreb, str. 5-27.

4. Čikić, J., Petrović, Ž. (2010): Organska proizvodnja i poljoprivredna gazdinstva Srbijeruralnosociološka analiza, Poljoprivredni fakultet, Novi Sad.

5. Čikić, J., Petrović, Ž. (2013): Diffusion of Knowledge and Innovations in Serbian Agriculture. In: Dragan Škorić, Danilo Tomić, Vesna Popović (eds.) Agri-Food Sector In Serbia State And Challenges, Belgrade: Serbian Academy of Sciences and Arts, Board for Village - Serbian Association of Agricultural Economics, pp. 91-118.

6. Hall, B. (2003): Innovation and Diffusion, Handbook on Innovation, Oxford University Press.

7. Janković, D. (2005): Teorija difuzije inovacija i njen dorpinos razumevanju inovativnog potencijala sela, Zbornik Matice srpske za društvene nauke, vol. 118-119, Novi Sad, str. 225-256.

8. Janković, D. (2012): Društvena uslovljenost sociološkog istraživanja ruralnog razvoja pristup sa stanovišta sociologije ruralnog razvoja, rad u tematskom zborniku Agroprivreda Srbije u pretpristupnom period, Društvo agrarnih ekonomista Srbije DAES, Volgograd State Agricultural University, Ekonomski institut Beograd, str. 109-123

9. Katić, B., Savić, M., Popović, V. (2010): Organska stočarska proizvodnja-neiskorišćena Šansa Srbije, Ekonomika poljoprivrede, Institut za ekonomiku poljoprivrede, Beograd, vol., pp. 245-256.

10. Kirchmann, H., Thorvaldsson, G. (2000): Challenging targets for future agriculture, 
European Journal of Agronomy, vol. 12, Elsevier, pp. 145-161.

11. Kun, T. (1974): Struktura naučnih revolucija, Beograd: Nolit.

12. Lampkin, N., Padel, S. (1994): The Economics of Organic Farming, an International Perspective, CAB International, London.

13. Lazić, B., Lazic, S. (2008): Organska poljoprivreda, monografija, Institut za ratarstvo i povrtarstvo, Novi Sad.

14. Leeuwis, C. (2008): Communication for rural innovation: Rethinking agricultural extension. UK: Blackwell Sciences.

15. Lockie, S., Halpin, D: (2005): The 'Conventionalisation'Thesis Reconsidered: Structural and Ideological Transformation of Australian Organic Agriculture, Sociologia Ruralis, Vol. 45, No. 4, UK, pp. 284-307.

16. Lowe, P., Phillipson, J., Lee, R. (2008): Socio-technical innovation for sustainable food chains: roles for social science, Trends in Food Science \& Technology 19, Elsevier Ltd, pp. 226-233

17. Morgan, K., Murdoch, J. (2000): Organic vs. conventional agriculture: knowledge, power and innovation in the food chain, Geoforum 31, Elsevier Science Ltd, pp. 159-173.

18. Offerman, F., Nieberg, H. (2000): Economic Performance of Organic Farms in Europe, University of Hohenheim, Germany.

19. Padel, S. (2001): Conversion to organic farming: a typical example of the diffusion of an innovation, Sociologia Ruralis, Vol. 41, UK, pp. 40-61.

20. Pejanović, R., Njegovan, Z. (2009): Preduzetništvo i (agro) ekonomija, monografija, Poljoprivedni fakultet, Novi Sad.

21. Petrović, Ž., Janković, D. (2010): Poljorivredno savetodavstvo Srbije-stanje problem i mogućnosti reforme, monografija, Poljoprivredni fakultet, Novi Sad.

22. Petrović, Ž., Samardžija, J., Janković, D. (2004): Problemi difuzije i uvođenja inovacija, znanja i tehnologija u seljačkoj poljoprivredi Srbije, Acta Agriculturae Serbica, Vol. IX, No. 17, Čačak, str. 633-643.

23. Ploeg, J. D. van der. (1995): From structural development to structural involution: The impact of new development in Dutch agriculture, in Ploeg J. D. van der and D. Dijk (eds.): Beyond modernization. The impact of endogenous rural development. Royal Van Gorcum. Assen.

24.Puđak, J., Bokan, N. (2011): Ekološka poljoprivreda-indikator društvenih vrednota, Sociologija i prostor, Institut za društvena istraživanja Zagreb, Zagreb, str. 137-163.

25. Rijn, F., Bulte, E., Adekunle, A. (2012): Social capital and agricultural innovation in Sub Saharan Africa, Agricultural Systems 108, Elsevier Ltd., pp. 112-122.

26. Rogers, E. (2003): Diffusion of innovations, Free Press, A Division of Simon \& Schuster, Inc., New York.

27. Sutherland, L., Darnhofer, I. (2012): Of organic farmers and 'good farmers': Changing habitus in rural England, Journal of Rural Studies no. 28, Elsevier ltd, pp. 232-240. 
28. Tovey, H. (1997): Food, Environmentalism and Rural Sociology: On the Organic Farming Movement in Ireland, Sociologia Ruralis, Vol. 37, No. 1, UK, pp. 21-37.

29. Vlahović, B., Radojević, V., Živanić, I. (2011): Istraživanje stavova potrošača o potrošnji organske hrane u Srbiji, Ekonomika poljoprivrede, Institut za ekonomiku poljoprivrede, Beograd, no. 3, pp. 443-456.

30. Woods, M. (2005): Rural Geography. Processes, Responses and Experiences in Rural Reconstructing, Sage Publications, London.

\title{
MOGUĆNOST PRIMENE TEORIJE DIFUZIJE INOVACIJA U ORGANSKOJ POLJOPRIVREDI ${ }^{8}$
}

\author{
Mirela Tomaš Simin', Dejan Jankovićc
}

\begin{abstract}
Rezime
Autori razmatraju mogućnost primene teorije difuzije inovacija na koncept organske poljoprivredne proizvodnje. Poljoprivredni i prehrambeni sektor je tokom prethodna dva veka bio izložen značajnim promenama, što je pokazalo značajnim fenomenom za teoriju difuzije inovacija koja je nastojala da bolje razume proces prenosa znanja $i$ usvajanja inovacija. Organska poljoprivreda se razvila kao odgovor na probleme zagađenja životne sredine a kasnije i druge probleme u konvencionalnoj proizvodnji uključujući i pitanja ruralnog razvoja. Cilj rada je da se upoznavanjem sa teorijom difuzije inovacija razmotri mogućnost njene primene na sistem organske proizvodnje, imajući u vidu sve njene specifičnosti, što otvara prostor za posmatranje samog sistema organske proizvodnje kao inovacije. Autori zaključuju da se teorija difuzije inovacija može koristiti prilikom istraživanja organskih sistema poljoprivredne proizvodnje, ali da se istraživanju mora pristupiti oprezno, uz obavezno uvažavanje svih njenih specifičnosti i karakteristika.
\end{abstract}

Ključne reči: organska poljoprivreda, inovacije, difuzija inovacija, usvajanje inovacija.

8 Rad je deo istraživanja na projektu broj III 46006 "Održiva poljoprivreda i ruralni razvoj u funkciji ostvarivanja strateških ciljeva Republike Srbije u okviru dunavskog regiona“ i projektu projektu ON 179028 „Ruralno tržište rada i ruralna ekonomija Srbije diverzifikacija dohotka i smanjenje siromaštva“.

9 Mirela Tomaš Simin, M.Sc., asistent, Univerzitet u Novom Sadu, Poljoprivredni fakultet, Trg Dositeja Obradović 8, 21000 Novi Sad, E-mail: mirelat@polj.uns.ac.rs

10 Doc. dr Dejan Janković, Univerzitet u Novom Sadu, Poljoprivredni fakultet, Trg Dositeja Obradović 8, 21000 Novi Sad, E-mail: jankovic@polj.uns.ac.rs

EP 2014 (61) 2 (517-529) 